\title{
95th Growth Percentile
}

National Cancer Institute

\section{Source}

National Cancer Institute. 95th Growth Percentile. NCI Thesaurus. Code C98267.

An indication that an individual ranks the same or more than 95 percent (top 5 percent) of the reference population for a given attribute. 